\title{
(2357) Proposal to reject the name Rosa ferruginea (Rosaceae), with a note on $R$. glauca
}

\author{
Joel Calvo, Carlos Aedo \& Félix Muñoz-Garmendia
}

Real Jardín Botánico-CSIC, Plaza Murillo 2,28014 Madrid, Spain - Author for correspondence: Joel Calvo,calvocasas@gmail.com

DOI http://dx.doi.org/10.12705/642.24

(2357) Rosa ferruginea Vill., Prosp. Hist. Pl. Dauphiné: 46. 16 Apr 1779, nom. utique rej. prop.

Typus: non designatus.

Rosa ferruginea was described by Villars in 1779 as a plant with leaves hirsute on both surfaces. Nine years later the author changed the epithet to rubrifolia and included the former name as a synonym. Thus, R. rubrifolia Vill. (Hist. Pl. Dauphiné 3: 549. 1788) is an illegitimate superfluous name under Art. 52.1 \& 52.2 of the Melbourne Code (McNeill \& al. in Regnum Veg. 154. 2012). Oddly, Villars depicted R. rubrifolia as a plant displaying glabrous leaves, which is not consistent with the former description of $R$. ferruginea. Unfortunately, no original material appears to exist for $R$. ferruginea (Crépin in Bull. Soc. Roy. Bot. Belgique 34: 79. 1895). Otherwise, two specimens labelled in Villars's handwriting under the name "Rosa rubrifolia" are kept at GRM. These specimens perfectly match with the description of $R$. rubrifolia, and indeed the leaves are glabrous. On this basis, the taxonomic entity of $R$. ferruginea seems to be confusing and difficult to elucidate. This issue was already highlighted by Burnat (Fl. Alpes Marit. 3: 44. 1899), who stated: "Le R. ferruginea de 1779 restera une Rose énigmatique; il ne parait pas en exister d'éch. authentiques et la description du Prospectus ne concorde ni avec celle de 1789 pour le R. rubrifolia, ni avec les spécimens à feuilles parfaitement glabres de cette dernière Rose, conservés dans l'herbier de Villars." Likewise, with reference to $R$. ferruginea Rouy (in Rouy \& Camus, Fl. France 6: 341. 1900) commented: "spec. Villars. valde dubia est, sed certe non R. rubrifolia e descript.!"

During the 19th century the name applied to the glabrous taxon was the illegitimate R. rubrifolia, e.g., Willdenow (Sp. Pl. 2: 1075. 1799), Candolle (in Lamarck \& Candolle, Fl. Franç., ed. 3, 4: 445. 1805), Lapeyrouse (Hist. Pl. Pyrénées: 284. 1813), Redouté (Roses 1: 31. 1817), Lindley (Ros. Monogr.: 104. 1820), Candolle (Prodr. 2: 609. 1825), Duby (Bot. Gall., ed. 2, 1: 177. 1828), Loiseleur-Deslongchamps (Fl. Gall., ed. 2, 1: 358. 1828), Desportes (Rosetum Gallicum: 90. 1828), Bertoloni (Fl. Ital. 5: 203. 1842-1844), Koch (Syn. Fl. Germ. Helv., ed. 2, 1: 249. 1843), Grenier (in Grenier \& Godron, Fl. France 1: 557. 1848-1849), Nyman (Syll. Fl. Eur.: 275. 1854-1855), Crépin (in Willkomm \& Lange, Prodr. Fl. Hispan. 3: 212. 1874), Burnat (Fl. Alpes Marit. 3: 43. 1899), Rouy (1.c.), Coste (Fl. Descr. France 2: 55. 1901). In contrast, the controversial name $R$. ferruginea was scarcely adopted (Grenier, Fl. Jurass. 3: 61. 1875; Déséglise in Bull. Soc. Roy. Bot. Belgique 15: 291. 1876; Nyman, Consp. Fl. Eur.: 235. 1878; Arcangeli, Comp. Fl. Ital.: 224. 1882). Other authors included the name in the synonymy of $R$. rubrifolia but excluded Villars's species concept (Rouy, 1.c.; Ascherson \& Graebner, Syn. Mitteleur. Fl. 6(1): 60. 1900).

On the other hand, the same taxonomic entity was described in 1788 by Pourret under the name $R$. glauca from plants collected in the Pyrenees. The name had almost fallen into oblivion (being included by some authors in the synonymy of $R$. rubrifolia) until Keller (Syn. Ros. Eur. Med.: 190. 1931) accepted it. A number of important reference books have since used it, e.g., Klášterský (in Tutin \& al., Fl. Eur. 2: 27. 1968), Silvestre \& Montserrat (in Castroviejo, Fl. Iberica 6: 173. 1998), Greuter (in Greuter \& Raab-Straube, Euro+Med Plantbase, http:// www.emplantbase.org, accessed Aug 2014), hence it is the current name applied to this species. It should be noted that $R$. glauca Pourr. has two illegitimate later homonyms that usually appear in the literature from the 19th century: $R$. glauca Desf. (Hist. Arbr. France: 165. 1809) and $R$. glauca Vill. ex Loisel. (in J. Bot. (Desvaux) 2: 336. 1809). The former is also illegitimate by being superfluous. Desfontaines, being unaware of Pourret's earlier homonym, renamed R. rubrifolia Vill. (and in our opinion there is no connection between Pourret's and Desfontaines's names). The latter belongs to the large and complex group of $R$. dumalis Bechst., which is still in need of a comprehensive nomenclatural revision.

According to Stafleu \& Cowan (in Regnum Veg. 110: 368. 1983) Pourret's specimens are kept at MAF and P. However, some of them were lost during his several moves. From a visit to MAF, we can confirm that there is no original material of $R$. glauca there. Grenier (1.c. 1875), Crépin (1.c. 1895), and Bubani (Fl. Pyren. 2: 595. 1899) documented the existence of one specimen at P. Unfortunately, our efforts to locate it with the kind help of the curator for historical collections were unsuccessful.

The presumed lack of extant original material leads us to propose a new specimen as type of the name. According to the protologue we select a recent collection from the Pyrenees. The type is kept at MA, and the isotypes are indicated below.

Rosa glauca Pourr. in Hist. \& Mém. Acad. Roy. Sci. Toulouse 3: 326. 1788 - Neotypus (hic designatus): Spain, Huesca, Sallent de Gállego, sendero del embalse de Respomuso, pr. la Sarra, $42^{\circ} 48^{\prime} 15^{\prime \prime} \mathrm{N} \mathrm{00} 20^{\prime} 10^{\prime \prime} \mathrm{W}, 1496$ m, 26 Jul 2014, J. Calvo \& É. RossNadié JC6688 (MA; isoneotypi: B, BM, G, GRM, K, MO, P, US, WU).

In summary, because of the homotypy of the two names under Art. 7.5 we might be led to typify R. ferruginea on one of the Villars specimens at GRM labelled "Rosa rubrifolia", but these do not match the description of $R$. ferruginea and thus cannot fit the sense originally intended by Villars. Moreover, we consider this action to be unnecessary for a controversial name that has been rarely in use. To resolve this problem and in order to preserve the current usage of the name $R$. glauca, the rejection of $R$. ferruginea is here proposed under Art. 56. Furthermore, a type is selected for the name $R$. glauca. Outright rejection of $R$. ferruginea seems the most effective way to establish a clear, stable nomenclature for this species.

\section{Acknowledgements}

We are grateful to Matthieu Lefebvre (GRM) and Cécile Aupic (P) for providing high-quality images of Rosa specimens and useful information respectively, as well as to Carmen Navarro and José Pizarro (MAF) for the facilities to study Pourret's collection. This work was financed by Flora iberica project (CGL2011-28613-C03-01). 